\title{
The Use of Decision Analysis and Watershed Modeling to Investigate E.coli Potential Sources and Solutions in Lake Tuscaloosa Watershed, Alabama
}

\author{
Laith S. Alfaqih and Robert E. Pitt
}

Lake Tuscaloosa, an artificial impoundment that serves as a public water supply, is located in Tuscaloosa and Fayette counties in the State of Alabama, in the Southeastern United States. Recent studies and monitoring of the lake show high levels of E.coli bacteria in the upper parts of the lake (near the main stream entrances) during periods of high stream flow. These high levels of E.coli are a concern for many different interested parties in the area. The city is under pressure to strengthen its management, monitoring, and control of existing and future pollutant sources (mostly land development) around the lake that is in its jurisdiction. Additionally, the city has to consider other sources of bacteria in the watershed outside of its jurisdiction as potential causes of these elevated bacteria levels.

The decision analysis framework and modeling schemes developed as part of this research examine flow, E.coli sources and transport issues, along with potential solutions. The decision analysis framework assisted at different stages of the project during the collection and management of the information that helped in the analysis of the problems and solutions. The flow and E.coli watershed models assisted in the analysis of the available data for the watershed to identify locations, seasons, and flow ranges

Alfaqih, L. and R.E. Pitt. 2009. "The Use of Decision Analysis and Watershed Modeling to Investigate E.coli Potential Sources and Solutions in Lake Tuscaloosa Watershed, Alabama." Journal of Water Management Modeling R235-01. doi: 10.14796/JWMM.R235-01.

(C) CHI 2009 www.chijournal.org ISSN: 2292-6062 (Formerly in Conceptual Modeling of Urban Water Systems. ISBN: 978-0-9808853-2-3) 
associated with the E.coli discharges. Developing a strategy to maintain the E.coli levels below the permissible limits in the watershed was challenging because many factors and information were needed for consideration during the data analysis and decision making parts of the research.

\subsection{Introduction}

The Lake Tuscaloosa watershed is located in Tuscaloosa and Fayette counties in the State of Alabama, in the Southeastern United States. The Lake, which was constructed on North River in 1970, serves as the major public water supply for the surrounding communities and is an important recreational water body in an area lacking in natural lakes. The watershed covers an area of approximately $1100 \mathrm{~km}^{2}$. The lake covers an area of approximately $24 \mathrm{~km}^{2}$ and it holds about 150 million $\mathrm{m}^{3}$ of water. The watershed and the lake are presented in Figure 1.1. This area normally has high rainfall (long term average of about $1400 \mathrm{~mm} / \mathrm{y}$ ), but is currently undergoing a severe drought, with about half of the normal rainfall having fallen during the last rain year. Even with this shortage, Lake Tuscaloosa has proven to be a reliable and sustainable water supply for the area. The reliability of this water supply has been an important component for the economy in the area.

Recent studies and monitoring of the lake have shown high levels of E.coli bacteria, especially in the northern parts of the lake (near the main river entrances) during periods of high stream flow (O'Neil, 2005). These high levels of E.coli have been identified as a concern for many stakeholders in the area. E.coli is a type of fecal coliform bacteria that is usually found in the intestines of warm blooded animals such as humans, cattle, birds, and different wild animals and is commonly used as an indicator of domestic sewage contamination and the presence of possible pathogens.

E.coli are mostly harmless bacteria commonly found in fecal discharges from warm blooded animals. Most strains are harmless, but some, most notably O157:H7, can cause serious illness in humans. In 1986, the EPA developed criteria for E.coli and Enterococci using currently accepted illness rates. These bacteria are assumed to be more specifically related to poorly treated human sewage than fecal coliforms. Many states and agencies therefore monitor E.coli as part of their surveillance monitoring activities. The typical analytical methods used are non-specific to the many E.coli stains; therefore, if E.coli are detected, it should not be assumed 
that pathogens are present or that human sewage contamination is responsible for the observed conditions.

E.coli can be introduced to the environment in various ways such as failing septic tanks, failing sewer systems (sanitary sewer overflows, (SSOs)), discharges of poorly treated sewage, contaminated urban stormwater, runoff from pastures and feedlots, residing birds, and even human fecal discharge from boats (Edge and Hill, 2007; Aslan-Yilmaz et al., 2004; Dietz et al., 2004; O'Shea and Field, 1992). E.coli occurrences in natural waters can be from sources other than sewage and animal wastes, such as reported in a recent study by Whitman et al (2006) where they found that once E.coli are established in the soil, the eroding soil can be a continuous source of E.coli to the nearby streams.

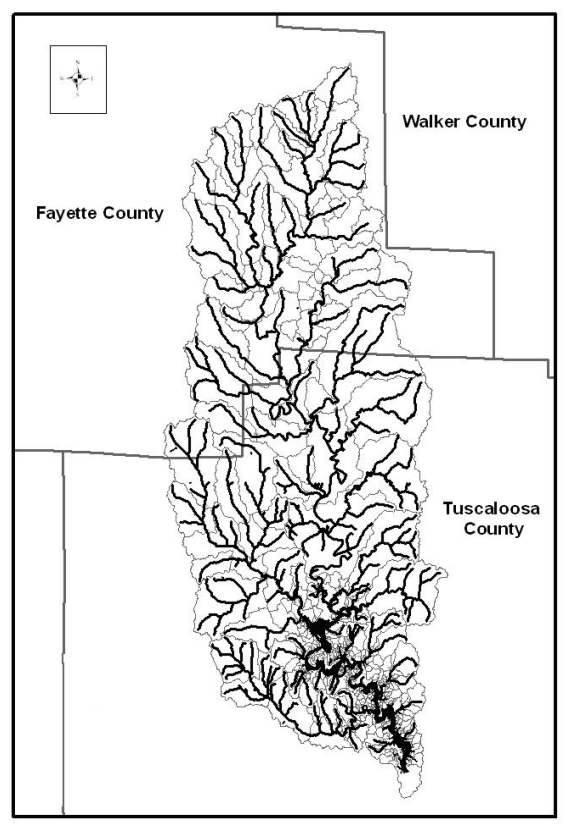

Figure 1.1 Lake Tuscaloosa watershed.

E.coli can persist in soils for relatively long periods after being discharged with the feces of these animals. They can then be transported to receiving waters during rains. These bacteria need warm soil and nutrients, promoting recolonization and growth in the soil (Whitman et al., 2006). 
Additionally, E.coli can persist in streams and stream sediments. High concentrations can be found at stormwater outfalls and are lowest at the headwaters of streams (Byappanahalli et al., 2004; Whitman and Nevers, 2003). Many factors can affect the movement of E.coli through a watershed, such as: the presence of activities in the watershed associated with concentrations of animals or wastewater treatment and disposal; and rainfall characteristics, with the E.coli count usually increasing quickly during a rain event but then declining to relatively low levels after the event ends (Whitman et al., 2006).

The City of Tuscaloosa is currently facing a challenging situation in dealing with increased urban development around the lake and in the watershed while protecting the lake from various pollutants, especially bacteria and nutrients. The city is therefore under pressure to strengthen its management, monitoring, and control of existing and future pollutant sources (mostly land development) around the lake that are in its jurisdiction. Additionally, the city has to consider other sources in the watershed outside of its jurisdiction as potential pollutant sources that are adversely affecting the water quality of the lake.

\subsection{Environmental Decision Analysis Framework}

A great deal of complexity arises from the necessity to incorporate an interdisciplinary set of theories and methodological approaches in order to address all the data, stakeholders and constraints involved in the problem of E.coli contamination of Lake Tuscaloosa (Klashner and Sabet, 2005). An Environmental Decision Analysis Framework (EDAF) was developed that recognizes this decision complexity and was implemented at the early stages of the project. The intention of this framework was to reduce the risk of failure of the critical infrastructure systems associated with this public water supply and recreational facility (Alfaqih, 2008).

The framework assists decision makers in identifying stakeholders' objectives and addresses the issues of stakeholders' priorities to help in the selection of robust and sustainable infrastructure systems. These objectives include, but are not limited to, economic, environmental and ecological, resources, ancillary infrastructure, regulatory, social and cultural, public health, and education and training. It also facilitates stakeholder objective traceability through the project assessment phase of environmental engineering management. This interaction between the framework and its various components with the project pre-planning phase is presented in Figure 1.2. 


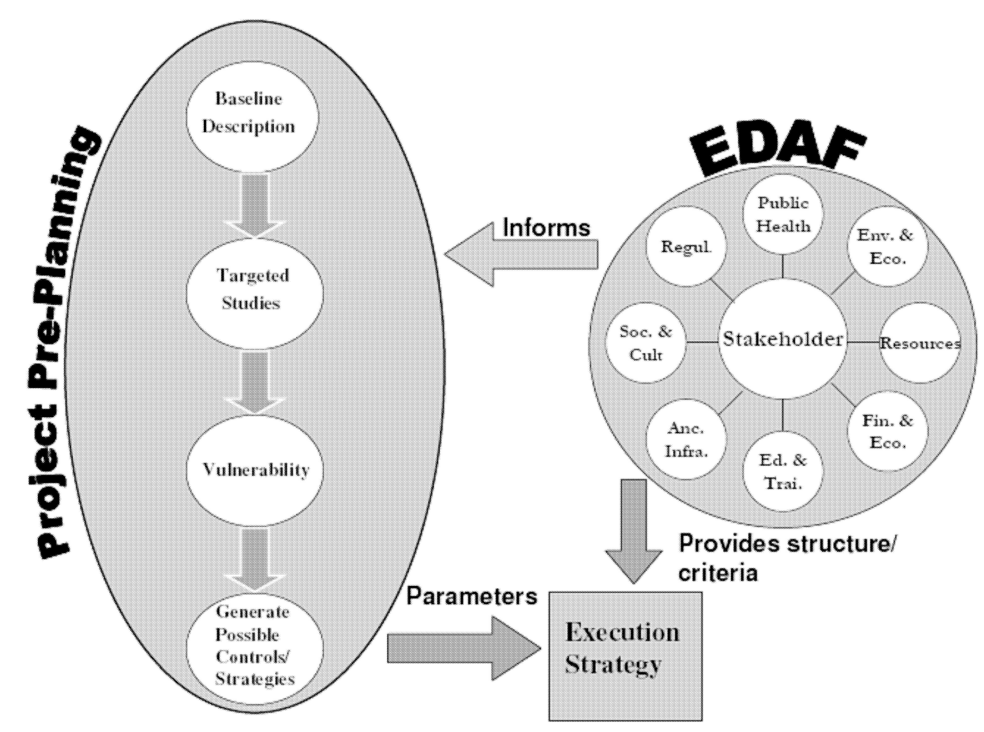

Figure 1.2 Interaction between the framework and the project pre-planning phases.

The EDAF assisted in identifying the major sources of bacteria pollution in the watershed and their relative impacts on the water quality downstream in the lake. The sources examined included agricultural activities (such as feedlot operations and chicken farms) and urban activities (such as stormwater discharges and sewage treatment plant discharges). The agricultural activities are located mainly in the northern portions of the watershed (upper ends of North River and Binion Creek), while the urban activities are mostly located in the southern portions of the watershed and along the lake shoreline.

Identifying sustainable and robust controls that can be implemented at the pollution sources are part of the decision making process. In order to select the most appropriate set of controls from the available alternatives, the flow and bacteria flux dynamics of the watershed subbasins need to be understood. This requires models describing the watershed hydrology/ hydraulics and the fate and transport of E.coli. The bacteria fate and transport model is dependent on the flow model because the river flows are the major transport mechanism of the water pollutants in the watershed subbasins and within the lake. 


\subsection{Flow Model}

Flow is generated through precipitation, where runoff from different landuses in the watershed flows into the adjacent creeks, streams and rivers until reaching its destination into Lake Tuscaloosa. The Lake Tuscaloosa watershed did not have an available watershed model for its different subbasins. Additionally, historical flow data are available only at three locations within the entire watershed at the lake's northern section. One location is near the confluence of North River where it connects with the lake. The second location is near the confluence of Binion Creek with the lake. The third location is in the center of the Turkey Creek drainage basin. These three recording stations are not sufficient to create a comprehensive understanding of the flow regime in the whole upper watershed area, but were suitable for calibrating a watershed model for the whole basin and verifying assumptions made for each subbasin.

Developing a flow model for large areas having limited data is challenging. Information about the subbasins, especially land cover and soil information, was not available, increasing the uncertainty in the model parameters and reducing the accuracy of the calculated results. As part of this research, much information needed to be collected in order to build a flow model that could be used to give a close representation of the actual system that could be verified using the available flow data.

\subsubsection{Data Used in Modeling}

The subbasins' delineation for the basins of interest, North River and Binion Creek, was obtained from the Geological Survey of Alabama (GSA). The description of each subbasin landuse was developed using aerial photos obtained from Google Earth ${ }^{\circledR}$ (http://earth.google.com). The soil data for each subbasin were obtained from the Web Soil Survey (WSS) provided by the Natural Resources Conservation Service (NRCS) (http://websoilsurvey.nrcs.usda.gov/ app/). The curve number $(\mathrm{CN})$, hydrological empirical parameter for predicting runoff or infiltration according to soil and ground cover, was determined from the soil and aerial photos in addition to the $\mathrm{CN}$ tables. The imperviousness values associated with buildings and roads were between $0-5 \%$ for the forest areas, which covers the majority of the basins. For agricultural activities, the values were between 2-10\% (Gunn et al., 2001; Cappiella and Brown, 2001; SCS, 1986).

The lag time values were calculated using WinTR-55 software (NRCS). Base flow data for the subbasins were not available. Therefore, the flow area 
distribution method was used to estimate the base flow for these subbasins (Viessman and Lewis, 2003).

In HEC-HMS, the NRCS method was used for calculating the flow in the basins (Scharffenberg and Fleming, 2006). The precipitation distribution was type III. There were no rain gauges within the watershed. The closest rain gauge during the duration of observed flows is a few miles away at the City of Tuscaloosa Municipal Airport. The flow data at the locations mentioned previously are available through the United States Geological Service (USGS). The flow data are registered on a daily basis and are available since 1939 for North River, since 1986 for Binion Creek and since 1981 for Turkey Creek.

There are four methods for calibration of flows in HEC-HMS: no action, curve number, initial abstraction, or SCS lag. Each method was examined during this project. The SCS lag parameter method was the most successful in calibrating the model to the observed data. The calculated results from the calibrated model, as discussed in the next section, were the closest to the observed values.

\subsubsection{Modeling Results}

The model for the Binion Creek basin had a higher correlation value when comparing the calculated flows to the observed flows than for the North River basin, possibly due to the differences in the sizes of the basins. The North River basin is almost three times the size of the Binion Creek basin which increases the uncertainty in the model parameters.

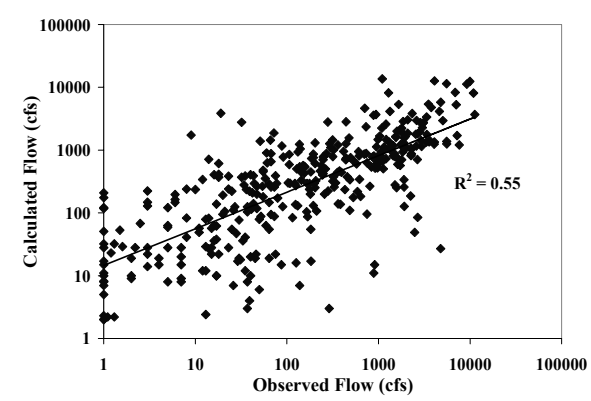

Figure 1.3 Observed flow versus calculated flow for North River.

The correlation between the observed and calculated flows for North River is presented in Figure 1.3 and for Binion Creek is presented in Figure 1.4. The results showed an $\mathrm{R}^{2}$ value of 0.55 for North River. The 
p-value for North River data at a $95 \%$ confidence interval is $<0.05$. Since the plot is not forced into the origin, a regression analysis was performed to indicate the significance of the intercept term. The p-value for the intercept is $0.51(>0.05)$. This indicates that the constant could be removed from the model; however this is not a common practice.

The $\mathrm{R}^{2}$ value is 0.88 for the regression equation comparing the observed and the calculated flows for Binion Creek. The p-value for Binion Creek data at a $95 \%$ confidence interval is $(<0.05)$. Similar to North River, the plot is not forced into the origin. A regression analysis was performed to indicate the significance of the intercept. The p-value for the intercept is $<0.05$. This indicates that the constant in the regression model can not be removed from the model.

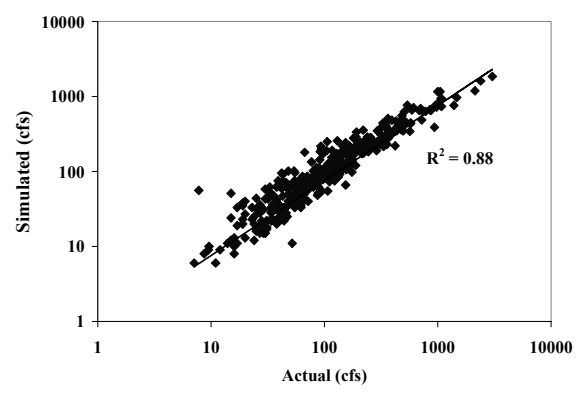

Figure 1.4 Observed flow versus calculated flow for Binion Creek.

The flow time series for the observed and calculated flows during 2005 for North River and Binion Creek basins are presented in Figure 1.5 A and B respectively.

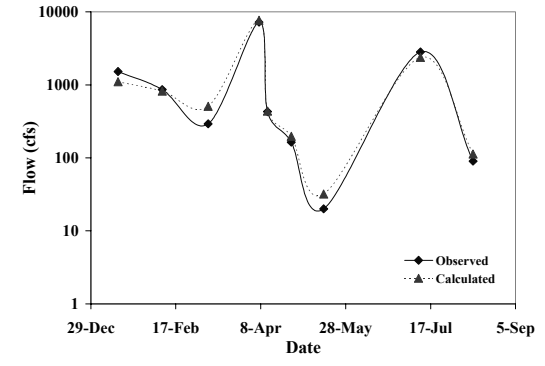

A

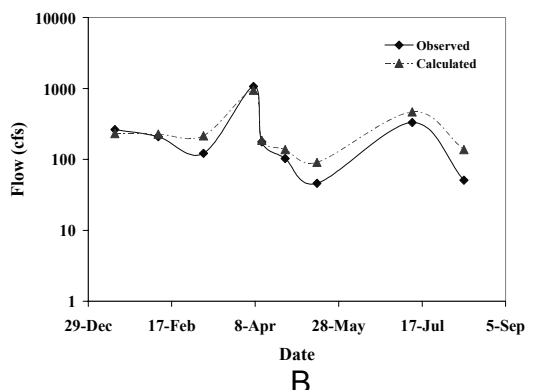

B

Figure 1.5 Flow time series for observed and calculated values during the periods of interest in 2005 at the reference points for North River $(A)$ and Binion Creek (B). 


\subsection{E.coli Model}

There has not been continuous monitoring of E.coli in the watershed, except within the lake itself. Approximately monthly E.coli measurements have been made by the City of Tuscaloosa at 32 locations since 1998. This city monitoring did not include investigating the potential source areas of E.coli in the watershed, which are considered in this research. The only comprehensive E.coli sampling for the entire watershed was conducted by GSA in 2005. Therefore, 2005 was the year used for developing the E.coli source and transport model. The E.coli modeling in the watershed conducted during this research was based on the literature from Pachepsky et al. (2006) and Thomann and Mueller (1997).

\subsubsection{Methodology}

The first step in modeling E.coli transport in the watershed is to map the transport path that the E.coli may take as it moves downstream. Mapping is important to establish the mass balance equations for the basin.

The load is calculated by multiplying the E.coli concentration by the flow from that subbasin. The equation is as follows:

$$
M_{\text {in }}=\sum_{i=1}^{n} Q_{i} C_{i}
$$

where:

$$
\begin{aligned}
\mathrm{Q}_{\mathrm{i}}= & \text { flow from subbasin (cfs), (calculated in the flow } \\
& \text { modeling section), } \\
\mathrm{C}_{\mathrm{i}}= & \text { E.coli concentration in the subbasin (cfu/100 mL), } \\
& \text { and } \\
\mathrm{n}= & \text { number of subbasins in a basin that provide flow. }
\end{aligned}
$$

Once the mass balance equations are set for the basin, the only unknown value needed in the model is the E.coli concentration, since we have the flow data from the watershed flow model. This concentration was determined from the E.coli model, as described below. The only E.coli concentration data available for the subbasins in the watershed are the ones provided by GSA. Trying to build a model from these data points was challenging because of the lack of data for each sampling location of interest.

Two phases are needed to calculate the E.coli concentration in the model. The first phase uses the known concentrations for a subbasin (obtained from the GSA observations) and finds the initial average amount of E.coli in that subbasin. These values become the seed/initial E.coli value from that 
subbasin for the second phase. In the second phase, the procedure is opposite to the first one, where the seed value is used to calculate the E.coli concentration at a subbasin under different precipitation events.

The first phase of the survival and inactivation of the microorganisms is modeled using an exponential equation suggested by Chick in 1908 and presented by Thomann and Mueller (1997) for bacteria modeling. This equation describes the survival rate of the microorganisms using a die-off (disappearance) rate constant:

$$
N=N_{0} \exp (-\mu t)
$$

where:

$$
\begin{aligned}
N= & \text { number of microorganisms after death at time } \mathrm{t}, \\
N_{0}= & \text { initial count of microorganisms at time } 0, \text { and } \\
\mu= & \text { die-off rate constant }\left(\text { day }^{-1}\right) . \text { The die off rate constant } \\
& \text { ranges between } 0.1 \text { and } 1 \text { per day. The initial count } \\
& \text { of microorganisms }\left(N_{0}\right) \text { has a unit of cfu } / \mathrm{g} \text { of soil. }
\end{aligned}
$$

The release of manure-borne microorganisms from the soil layer during rain events can be calculated exponentially. Many models have been suggested, but the one used is the equation developed by Bicknell et al. (1997).

$$
\Delta M_{R}=M_{S}\left[1-\exp \left(-k_{2} \Delta Q\right)\right]
$$

where:

$$
\begin{aligned}
\Delta M_{R}= & \text { count of microorganisms released during a runoff } \\
& \text { event }(\mathrm{cfu} / \mathrm{g}) \\
M_{S}= & \text { count of microorganisms in the storage layer of soil } \\
& (\mathrm{cfu} / \mathrm{g}) \\
\Delta Q= & \text { runoff yield during runoff event }(\mathrm{cm}), \text { and } \\
k_{2}= & \text { release rate parameter }\left(\mathrm{cm}^{-1}\right) . \text { This value ranges } \\
& \text { between } 2 \text { (for pasture) and } 5 \text { (impervious areas) } \\
& \text { depending on the landuse. }
\end{aligned}
$$

The $\Delta Q$ value needs to be converted from $\mathrm{cfs}$ to $\mathrm{cm}$. The flow was divided by basin area to transform flow units (cfs) into depth units $(\mathrm{cm})$.

Next, the concentration of the E.coli in the water is calculated using the following linear isotherm equation (Sadeghi and Arnold, 2002; Bicknell et al., 1997). Since the unit of $\mathrm{C}$ is $\mathrm{cfu} / \mathrm{mL}$, in order to make it $\mathrm{cfu} / 100 \mathrm{~mL}$ the $\mathrm{C}$ value is divided by 100 . 


$$
C=\frac{S}{k_{d}}
$$

where:

$$
\begin{aligned}
\mathrm{C}= & \text { concentration of } \text { E.coli in water } \mathrm{cfu} / \mathrm{mL}, \\
\mathrm{S}= & \text { amount of microorganisms in runoff }(\mathrm{cfu} / \mathrm{g}) \text {, and } \\
\mathrm{k}_{\mathrm{d}}= & \text { partitioning coefficient }(\mathrm{mL} / \mathrm{g}), \text { its value is between } \\
& 10 \text { and } 70 \mathrm{~mL} / \mathrm{g} .
\end{aligned}
$$

The model described above determines the concentration of E.coli in the water after being released from a contaminated surface source. In order to calculate the initial microorganism number, the process is reversed using Equation 1.7 first and going to Equation 1.4. This entire process is presented in Table 1.1. The forward model table is similar to the one presented below, the only difference is the organization of the parameters.

Table 1.1 Variables and units used in the model.

\begin{tabular}{lll}
\hline Cwater & $\mathrm{cfu} / 100 \mathrm{~mL}$ & E.coli count in water \\
\hline Cwater & $\mathrm{cfu} / \mathrm{mL}$ & \\
Q subbasin & $\mathrm{cfs}$ & Subbasin flow \\
A subbasin & $\mathrm{sq}-\mathrm{ft}$ & Subbasin Area \\
$\Delta \mathrm{Q}$ & $\mathrm{cm}$ & \\
$\mathrm{Kd}$ & $\mathrm{mL} / \mathrm{g}$ & The partitioning coefficient value \\
$\mathrm{S}$ & $\mathrm{cfu} / \mathrm{g}$ & Amount of microorganisms in runoff \\
$\mathrm{K} 2$ & $/ \mathrm{cm}$ & Release rate parameter \\
$\Delta \mathrm{Mr}$ & $\mathrm{cfu} / \mathrm{g}$ & $\begin{array}{l}\text { Count of microorganisms released during } \\
\text { a runoff event }\end{array}$ \\
$\mathrm{Ms}$ & $\mathrm{cfu} / \mathrm{g}$ & $\begin{array}{l}\text { Count of microorganisms in manure storage layer } \\
\text { of soil }\end{array}$ \\
$\mathrm{N}$ & $\mathrm{cfu} / \mathrm{g}$ & Count of microorganisms after die off \\
$\mu$ & $/ \mathrm{day}$ & Die-off rate \\
$\mathrm{t}$ & Day & Original count of microorganisms \\
$\mathrm{N} 0$ & $\mathrm{cfu} / \mathrm{g}$ & \\
\hline
\end{tabular}

The calculated concentrations along with the flow from the subbasin are the values that are entered into the mass balance model as presented in Equation 1.3. These calculations of concentrations and the mass balance model are developed in Excel. The spreadsheets were developed for every precipitation event under consideration. The E.coli values produced from the mass balance equations were compared with the observed readings downstream in order to calibrate and verify the model. 


\subsubsection{E.coli Model Calibration}

In the E.coli model, there are many variables that are uncertain. The first of these variables is in Equation 1.2 the die-off rate $\mu$. The second is the $\mathrm{k}_{2}$ value in Equation 1.3. The third is the $\mathrm{k}_{\mathrm{d}}$ value in Equation 1.4. Finally, there is uncertainty in modeling the flow values for the subbasins. Each one of these variables impacts the calculated E.coli concentrations in the model.

Each subbasin is calibrated separately in the model in order to observe its impact downstream. Also, the calibrations were conducted for every precipitation event separately. The majority of the variables in the model are obtained from the literature, such as the $\mathrm{K}_{\mathrm{d}}, \mu$ and $\mathrm{K}_{2}$. However, they do not have as much impact on the concentration as the decay time. If the decay time is shorter, then the microorganisms' concentration in the water is larger than if the decay time is longer due to the dieoff of the bacteria that occurs with time. The (t) variable may be larger than expected due to natural causes, such as obstacles in the waterways, causing ponding that is seldom considered during typical hydraulic river flow modeling during large events. Further information about the calibration, data, and results are presented in Alfaqih, 2008.

\subsubsection{Model Results and Analysis}

The calculated values were compared with the observed values at the reference point located downstream from each basin. The precipitation depths were plotted against the observed and calculated values of E.coli for the North River basin in Figure 1.6. This plot shows a correlation between the precipitation and E.coli, where the larger rains are associated with higher E.coli values.

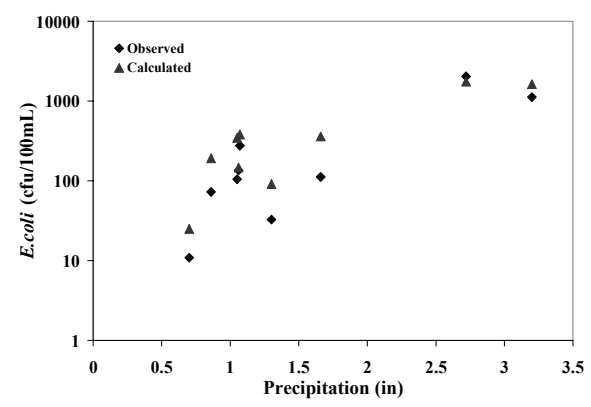

Figure 1.6 E.coli observations plotted against precipitation depth for North River. 
The plot in Figure 1.7, shows the time series for both the observed and modeled E.coli values at the reference point for North River basin. This plot shows that the modeled E.coli values follow the observed ones reasonably closely. The one way ANOVA test gave a p-value $0.37(>0.05)$, indicating that more data would be needed to be confident at the $95 \%$ level that the sets of data are different. The results from Binion Creek also had similar trends with the observed and the modeled values and the ANOVA test gave a p-value $0.46(>0.05)$.

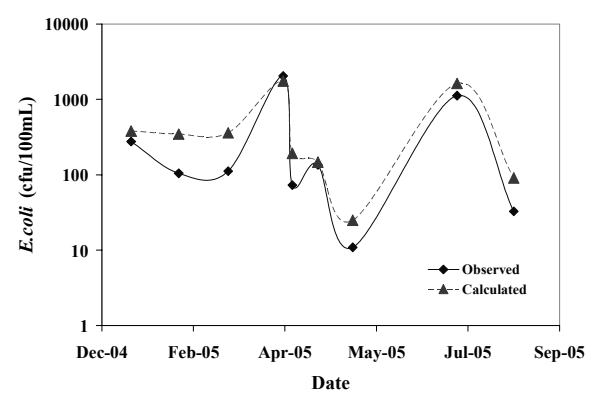

Figure 1.7 Observed and calculated E.coli time series for North River.

\subsection{Investigating and Choosing Controls}

The developed E.coli models for both North River and Binion Creek basins were used to study and analyze the impacts of the sources of bacteria on the water quality in the lake. The maximum allowable load released from the subbasins needs to be set in order to minimize the impact on the lake.

In this investigation, the potential sources responsible for the E.coli contamination of the lake are tested in terms of their potential impact on the water quality downstream. This investigation is performed through the E.coli model. The potential sources under consideration are agricultural activities (feedlot operations and chicken farms) and urban (wastewater treatment plants and septic tanks). The locations containing these activities may need to implement controls on their properties to reduce their negative impact on the water quality in the lake.

The first group of potential sources that were considered was the agricultural activities. Various scenarios for controlling these agricultural activities were tested. For example, two scenarios were to implement controls for only 25 and $50 \%$ of these activities respectively. Another scenario was to implement controls on all the activities. Additionally, different E.coli 
concentration values were tested to replace the current values at the sources of pollution. These values represent the maximum allowable concentrations released by the controls under consideration. The concentration values ranged between 150 and $600 \mathrm{cfu} / 100 \mathrm{~mL}$.

The second potential sources that were considered were the wastewater treatment plant and septic tanks. Controls were implemented on these activities and tested in the E.coli model. Different ranges of E.coli concentration values were substituted in the model to show the impact on the lake. The range of values substituted in the treatment plant ranged from hundreds to thousands of $\mathrm{cfu} / 100 \mathrm{~mL}$.

After running these scenarios, the results and the analysis showed that there were negligible impacts associated with the urban activities on the water quality in the lake. The main activities responsible for E.coli problems were found to be the agricultural activities. All of these agricultural activities should implement controls to reduce the E.coli levels as much as possible. The discharges from these areas, after control, should not exceed $200 \mathrm{cfu} / 100 \mathrm{~mL}$ at any time. This would maintain the water quality downstream in the lake to at, or below, the City of Tuscaloosa's limit $(200 \mathrm{cfu} / 100 \mathrm{~mL})$. The plot in Figure 1.8 shows the probability of exceeding the city's limit by implementing the different control scenarios. This figure indicates that a subbasin in either North River or Binion Creek watersheds has a probability of exceeding an E.coli count $>200$ of at least 0.40 (a $40 \%$ chance of exceeding the standard during any runoff event), with this probability increasing as the flow increases, especially without implementing any controls on the sources of pollution in the agricultural areas.

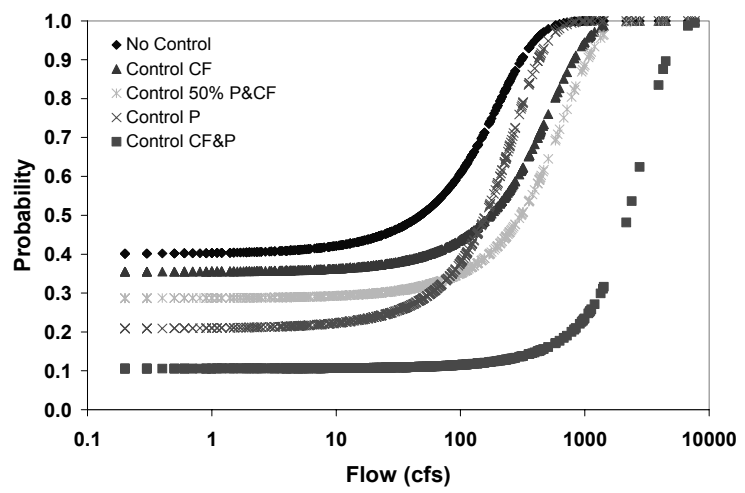

Figure 1.8 Probability plot for implementation of different control scenarios in both North River and Binion Creek basins [CF: Chicken Farm and P: Pasture]. 
The probability plot, Figure 1.8, was used to calculate the percentage of time the E.coli concentrations would likely exceed the limit during a typical period of rains. The typical rain periods used were for the 1975 and 1976 rain events. These were chosen based on earlier evaluations of all rains from 1955 to 1986 and it was found that these years had rains that were the closest to the average conditions (on a monthly and yearly basis) (Pitt and Clark, 2002). The probability for every flow event for this period exceeding the E.coli limit was determined and a histogram was prepared, as shown in Figure 1.9. This histogram shows that if no controls were to be implemented, $60 \%$ of the rain events would result in the E.coli levels in the lake being above the limit. If controls were implemented, then the percentage of rains exceeding the limit would be reduced to as low as $10 \%$.

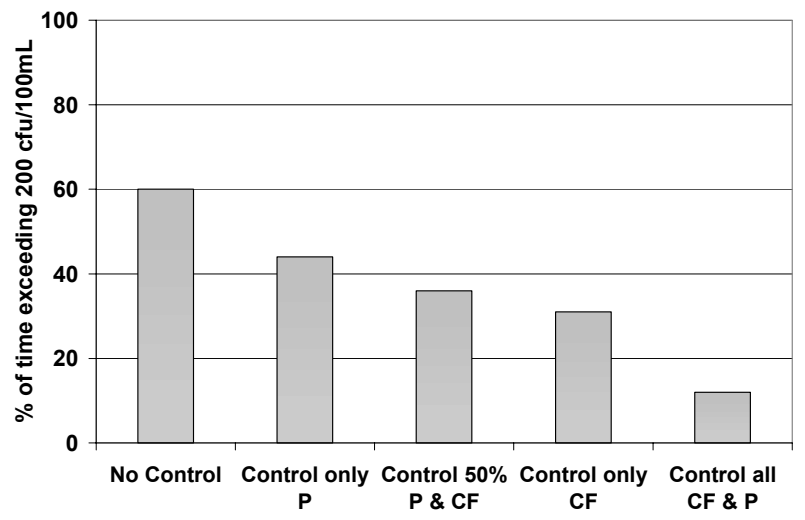

Figure 1.9 Percentage of rains the E.coli levels in the lake would exceed the $200 \mathrm{cfu} / 100 \mathrm{~mL}$ limit.

\subsubsection{Control Alternatives}

This section discusses the potential alternatives that may be used to control the E.coli problem in the Lake Tuscaloosa watershed. Seventeen alternatives were initially studied. These alternatives went through an initial cut phase. This was based on comparing initial modeling results and then focusing on those that had the greatest potential for significant benefits. The final list was reduced to seven alternatives: two alternatives are for controlling animal access to close waterbodies while the other five alternatives are for manure management. 


\section{Animal Access Alternatives}

The two alternatives to control animal access to nearby waterbodies are prescribed grazing and the use of buffer zones. Prescribed grazing is where animals are managed and controlled within the pasture through fencing. Buffer zones, such as a riparian forest buffer, consist of trees with bushes and shrubs along the waterbody to hinder access of the animals to the waterbody. In order to have successful implementation of these alternatives, remote drinking units need to be installed at different locations within the pasture to keep the pasture animals (cows and horses) out of the river.

\section{Manure Management Alternatives}

Agricultural activities in the Lake Tuscaloosa watershed lack manure management plans. This has likely led to the majority of the E.coli problems in the watershed. Five manure management alternatives were further examined: incineration, approved burial sites, waste storage structures, composting and filter strips.

The information about these alternatives was obtained from the Environmental Decision Analysis Framework (EDAF). The information was categorized under each facet of the framework. The framework gave an additional detailed depth to the specifications of the alternatives. It gave economic, ecological and environmental, public health, education and training, regulatory, infrastructure, social and cultural and resources information about these alternatives. The information generated about these alternatives in the EDAF is used in the decision analysis process discussed in the next section.

\subsubsection{Implementing Decision Analysis for Choosing Controls}

The comparison and selection of robust and sustainable controls is conducted according to multiobjective decision making. The implemented procedure was previously described in prior proceedings from this conference series (Pitt and Voorhees, 2007). This procedure is based on methods developed and described by Keeney and Raiffa (1976). In this section, a summary of the procedure and the results of its implementation to investigate the E.coli problems in the Lake Tuscaloosa watershed are discussed.

In this multiobjective analysis, relatively few objectives were chosen in order to demonstrate the analysis in a relatively simple manner. These objectives included: minimizing threats to public health, minimizing costs to the stakeholders, and minimizing pollutants discharged into the environment 
(including total solids, phosphorus $(\mathrm{P})$, nitrogen $(\mathrm{N})$ and air pollution in terms of $\mathrm{CO}_{2}$ reduction).

The first step after identifying the alternatives was to present the resultant values for each objective associated with each alternative after running the models for the watershed. Other values were obtained from Measures to Control Nonpoint Pollution from Agriculture published by the US EPA (2003). These values are presented in Table 1.2. The negative sign in the air pollution column indicates reductions in emissions compared to current practices and the negatives in the cost column indicate income associated with the practice.

Table 1.2 Values of the objectives for manure management alternatives.

\begin{tabular}{|c|c|c|c|c|c|c|c|}
\hline & \multirow{2}{*}{$\begin{array}{l}\text { Facets } \\
\text { Objective }\end{array}$} & Public & \multicolumn{4}{|c|}{ Environment and Ecology } & \multirow{2}{*}{$\begin{array}{l}\text { Economic } \\
\\
\text { Cost } \\
\$ / \text { ton }\end{array}$} \\
\hline & & $\begin{array}{c}\text { E.coli } \\
\% \\
\end{array}$ & $\begin{array}{l}\mathrm{P} \\
\%\end{array}$ & $\begin{array}{l}\mathrm{N} \\
\%\end{array}$ & $\begin{array}{c}\text { Sediment } \\
\%\end{array}$ & $\begin{array}{c}\text { Air } \\
\text { Pollution } \\
\mathrm{CO}_{2} \mathrm{eq} / \mathrm{yr}\end{array}$ & \\
\hline & Alternatives & & & & & & \\
\hline 1 & Incineration & 100 & 100 & 100 & 100 & -2434 & 10.0 \\
\hline 2 & Burial Sites & 100 & 100 & 100 & 100 & 0 & 10.8 \\
\hline 3 & Waste Storage & 90 & 60 & 65 & 70 & 0 & 3.0 \\
\hline 4 & Composting & 100 & 90 & 80 & 60 & -8291 & -24.0 \\
\hline 5 & Filter Strip & 55 & 85 & 70 & 60 & 0 & 37.5 \\
\hline
\end{tabular}

\footnotetext{
${ }^{1}$ These are reductions in the percentages of rain events that exceed the E. coli objectives in the lake, based on the watershed modeling.
}

Table 1.3 Alternatives' facets and their objectives, units of measure and ranges.

\begin{tabular}{lcccc}
\hline Facet & Measure & Units & Best & Worst \\
\hline Public Health & E.coli & $\%$ & 100 & 55 \\
Environment & Phosphorus (P) & $\%$ & 100 & 60 \\
and Ecology & Nitrogen (N) & $\%$ & 100 & 65 \\
& Sediment & $\%$ & 100 & 60 \\
& Air Pollution & $\mathrm{CO}_{2}$ eq/yr & -8291 & 0 \\
Economic & Cost & \$/ton & -24 & 37.5 \\
\hline
\end{tabular}


The second step was to summarize the information presented in Table 1.2 in terms of the units of the measure and the range of operational values for each facet, presented as best and worst outcomes. This information is presented in Table 1.3.

The third step was quantifying the utility curves for each objective. The utility curves represent the approach of the decision makers towards risk. The main concerns in developing the utility curves are identifying the upper, lower and the middle points of the curve. Afterwards the shape of the curve is determined through the knowledge of the objective. An example of the utility curve for the cost objective is presented in Figure 1.10. The best utility is assigned a 1.0 (the least cost), while the worst utility is assigned a 0.0 (the highest cost). Intermediate costs are assumed to be linearly associated with utility values (a straight line).

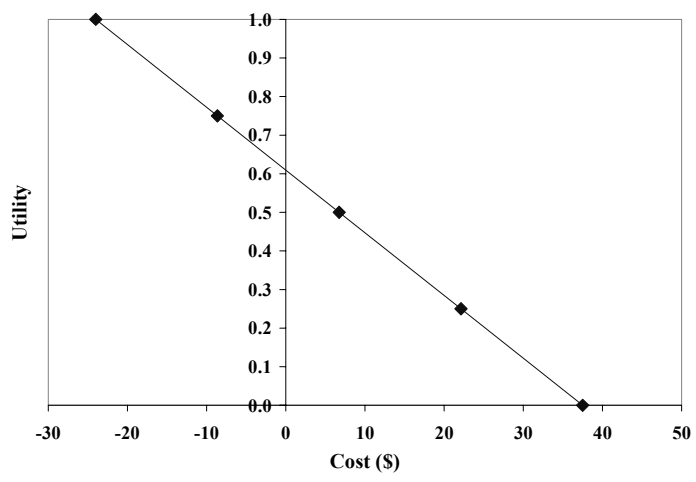

Figure 1.10 Minimize cost utility curve.

The fourth step was to establish the tradeoffs between the objectives for each group of stakeholders. This step needed the direct input from the stakeholders. The presented tradeoff scenario in this chapter is hypothetical.

The stakeholders rank the objectives from the most to the least important. After ranking the objectives, the tradeoffs between them (the sum of the tradeoffs must equal 1.0) are determined by pairing the objectives (worst, best) with (?, worst). The (?) or the unknown value for that objective was established when the stakeholder reached a point of indifference $(\cong)$ between the two pairs of values. The common comparison parameter between the objectives in the tradeoffs was the cost (U.S.\$).The first tradeoff was between E.coli and cost. The compared values were $(55 \%,-\$ 24) \cong($ ?, $\$ 37.5)$. The (?) value was assumed to be $80 \%$, indicating that an $80 \%$ reduction at a 
high cost (\$37.5) was equivalent to the lowest reduction (55\%) at the lowest cost (actually a profit). The results from the rest of the pairs are summarized below.

Public Health, Cost: $(55 \%,-\$ 24) \cong(80 \%, \$ 37.5)$

Cost, N: $(\$ 37.5,100 \%) \cong(\$ 37.5,65 \%)$

Cost, Sediment: $(\$ 37.5,100 \%) \cong(\$ 37.5,60 \%)$

Cost, Air pollution: $(\$ 37.5,-8291) \cong(\$ 37.5,0)$

Cost, P: $(\$ 37.5,100 \%) \cong(\$ 37.5,60 \%)$

This information was used to calculate the tradeoff constant $(\mathrm{k})$ values for every objective using a set of simultaneous equations, with the tradeoff constants for each facet being summed to equal 1.0. The utility curves and tradeoff constants were used in calculating the utility value (step 6) using the multiobjective utility function. This function is presented below.

$$
u\left(x_{1}, x_{2}, x_{3}, x_{4}, x_{n}\right)=\sum_{i=1}^{n} k_{i} v_{i}\left(x_{i}\right)
$$

where:

$$
\begin{aligned}
x_{i} & =\text { the level of the } \mathrm{i}^{\text {th }} \text { attributes, } \\
u\left(x_{i}\right) & =\text { the utility of the } \mathrm{i}^{\text {th }} \text { individual objective, } \\
v & =\text { the multiobjective utility, and } \\
k_{i} & =\text { trade-off constant for } \mathrm{i}^{\text {th }} \text { objective. }
\end{aligned}
$$

The fifth step in this procedure was to assign the utility values for each objective for every control alternative examined. These utility values are presented in Table 1.4.

Table 1.4 Utility values for the related objectives for every control alternative.

\begin{tabular}{lcccccc}
\hline & \multicolumn{5}{c}{ Objectives } \\
\hline Alternative & E.coli & Cost & $\mathrm{P}$ & $\mathrm{N}$ & Sediment & Air pollution \\
Incineration & 1.00 & 0.48 & 1.00 & 1.00 & 1.00 & 0.30 \\
Burial Sites & 1.00 & 0.47 & 1.00 & 1.00 & 1.00 & 0.00 \\
Waste Storage & 0.77 & 0.55 & 0.00 & 0.00 & 0.25 & 0.00 \\
Composting & 1.00 & 1.00 & 0.75 & 0.49 & 0.00 & 1.00 \\
Filter Strip & 0.00 & 0.40 & 0.55 & 0.15 & 0.00 & 0.00 \\
\hline
\end{tabular}

The sixth and final step was to calculate the utility for every alternative. This was conducted by using the multiobjective utility function equation. The utility value for the objective for an alternative is multiplied by the 
relative $\mathrm{k}$ value for that objective. This calculation assigns every alternative a utility value. These values are presented in Table 1.5.

Table 1.5 Utility for each alternative.

\begin{tabular}{lc}
\hline \multicolumn{1}{c}{ Alternative } & Utility \\
\hline Incineration & 0.81 \\
Burial Sites & 0.80 \\
Waste Storage & 0.69 \\
Composting & 1.00 \\
Filter Strip & 0.15 \\
\hline
\end{tabular}

These utility values indicate that according to the multiobjective decision analysis the composting alternative had the highest utility value, followed by incineration and burial sites that were basically tied. Waste storage and filter strips had the least desirability.

\subsection{Conclusions}

This chapter covered three main phases. The first phase identifies the problem and the sources of pollution. The second phase models the flow and the fate and transport of the E.coli. Finally, the third phase identifes and chooses the controls that need to be implemented.

The EDAF is a tool that is used at the front end planning of the project. It helps identify the sources of pollution in the area under study, by identifying and collecting available data and information from the stakeholders about the problem. It assists in the organization of the data related to the project to be easily analyzed. Additionally, it assists in developing the specifications of the controls to be implemented at the sources of pollution. This is conducted by organizing the available data about the controls according to the facets of the framework.

The modeling of flow, along with the fate and transport of E.coli in the watershed was challenging. Many parameters had uncertainty associated with them. This uncertainty was due to the limited data available and their inherent variability. A sensitivity analysis was performed on these parameters to identify their impact on the results. The results from the modeling showed that the calculated values were reasonably close to the observed values at the available points of reference where historical data had been collected. Although the calculated and observed values were close at these locations, it does not imply that the calculated values at other locations 
in the watershed are as close as observed at the reference locations. Since only a few locations were available to verify the model, it was recommended that additional data be collected at other locations to increase the confidence of the modeling and the decision analysis results.

These analyses indicated that a comprehensive pollution management plan needs to be implemented in the watershed. All the sources of pollution have to implement effective controls to maintain the water quality in the lake to within the city's limit.

The analysis of the alternative controls to reduce the impacts of discharges on the E.coli levels in the lake also examined a variety of other worthwhile objectives, such as $\mathrm{CO}_{2}$ emissions, nutrient discharges, and costs. There are several control alternatives that could benefit many of the stakeholders. For example, selecting manure composting as a control would not only reduce E.coli and other pollutants, but could also become a source of possible revenue for the farmers.

\section{Acknowledgment}

The authors would like to acknowledge the Aging Infrastructure Systems Center of Excellence (AISCE) at The University of Alabama for funding this project, and the various entities that have provided the data: The City of Tuscaloosa, Black Warrior River Keepers and the Geological Survey of Alabama (GSA).

\section{References}

Alfaqih, L, 2008. Application of Environmental Decision Analysis Framework on the E.coli Problem in Lake Tuscaloosa Watershed. Dissertation, The University of Alabama.

Aslan-Yilmaz, A., E. Okus, and S. Ovez, 2004. Bacteriological s of anthropogenic impact prior to and during the recovery of water quality in an extremely polluted estuary. Marine pollution bulletin 49: 951 - 958.

Bicknell, B., J. Imhoff, J. Kittle, Jr., A. Donigan, Jr., and R. Johanson, 1997. Hydrological Simulation Program Fortran, User's Manual for version 11, Research Triangle Park, North Carolina.

Byappanahalli, M. and R.S. Fujioka, 2004. Indigenous soil bacteria and low moisture may limit but allow fecal bacteria to multiply and become a minor population in tropical soils. Water Science Technology 50: 27 - 32.

Cappiella, K. and K. Brown, 2001. Watershed protection techniques. Landuse and impervious cover in the Chesapeake Bay Region 3, no. 4: 835-840. 
Dietz, M. E., J. C. Clausen, and K. K. Filchak, 2004. Education and changes in residential non-point source pollution. Enviromental Management 94: 71 - 79.

Edge, T., and S. Hill, 2007. Multiple lines of evidence to identify the sources of fecal pollution at a freshwater beach in Hamilton Harbour, Lake Ontario. Water Research 41, no. 16: $3585-3594$

Gunn, R., J. Frankenberger, and B. Engel, 2001. A method for understanding the hydrologic implication of comprehensive land use plans. In ESRI User Conference:919.

Keeney, R. and H. Raiffa, 1976. Decisions with Multiple Objectives. Cambridge: Cambridge University Press.

Klashner, R. and S. Sabet, 2005. A DSS design model for complex problems: Lessons from mission critical infrastructure. Decision Support Systems.

O'Neil, P., M. R. Cook, W. P. Henderson, and N. R. Moss, 2005. Distribution and concentration of total coliform and Escherichia coli bacteria in the north river/lake Tuscaloosa watershed. Tuscaloosa, AL: Water investigations program, Opn-File report 0604.

O'Shea, M.L. and R. Field, 1992. Detection and disinfection of pathogens in storm generated flows. Canadian Journal of Microbiology 38: 267 - 276.

Pachepsky, Y. A., A. M. Sadeghi, S. A. Bradford, D. R. Shelton, A. K. Guber, and T. Dao, 2006. Transport and fate of manure borne pathogens: Modeling perspective. Agricultural Water Management, no. 86: 81 - 92.

Pitt, R. and S. Clark, 2002. Regional rainfall conditions and site hydrology for construction site erosion evaluations. In Construction site erosion control for highway projects.

Pitt, R.E. and J. Voorhees. 2007. "Using Decision Analyses to Select an Urban Runoff Control Program." Journal of Water Management Modeling R227-04. doi: 10.14796/JWMM.R227-04.

Sadeghi, A. M. and J. G. Arnold, 2002. A swat/microbial sub-model for predicting pathogen loadings in surface and ground water at watershed and basin scales. In Total Maximum Daily Load (TMDL) Environmental Regulations, 70P0102:56-63. Fort Worth, Texas, USA: ASAE Publication.

Scharffenberg, W. A. and M. J. Fleming, 2006. HEC-HMS User's Manual. Washington DC: US Army Corps of Engineers.

SCS, (Soil Conservation Service). 1986. Urban Hydrology for Small Watersheds. US Department of Agricultural Soil Conservation Service, Technical Release 55.

Thomann, R. V. and J. A. Mueller, 1987. Principles of Surface Water Quality Modeling and Control. New York, NY: HarperCollinsPublishers Inc.

US EPA, (Environmental Protection Agency). 2003. National management measures to control nonpoint pollution from agriculture. Washington, D.C., EPA-841-B-03-004.

Viessman, W. and G. Lewis, eds. 2003. Introduction to Hydrology. Upper Saddle River, NJ: Pearson Education, Inc.

Whitman, R. and M. B. Nevers, 2003. Foreshore sand as a source of Escherichia coli in near shore water of a lake Michigan beach. Applied and Environmental Microbiology 69: 5555 - 5562.

Whitman, R., M. B. Nevers, and M. Byappanahalli, 2006. Examination of the watershedwide distribution of Escherichia coli along southern Lake Michigan: An integrated approach. Applied and Environmental Microbiology 72, no. 11: 7301-7310. 